\title{
The Impact of the Environmental Condition on the Performance of the Photovoltaic Cell
}

\author{
Ehsan Fadhil Abbas Al-Showany \\ Refrigeration \& Air Conditioning Engineering Department, Kirkuk Technical College, Northern Technical University, Kirkuk, Iraq
}

\section{Email address:}

ehsanfadhil@gmail.com

\section{To cite this article:}

Ehsan Fadhil Abbas Al-Showany. The Impact of the Environmental Condition on the Performance of the Photovoltaic Cell. American Journal of Energy Engineering. Vol. 4, No. 1, 2016, pp. 1-7. doi: 10.11648/j.ajee.20160401.11

Received: March 7, 2016; Accepted: March 15, 2016; Published: March 31, 2016

\begin{abstract}
The present study investigated the impact of weather conditions on the production performance of the photovoltaic (PV) module. The experiments have been conducted by using two identical PV module of 75 Watt each and they were placed in the same weather conditions in the summer season in Kirkuk city-Iraq. One of them was used as a conventional module as a reference panel and the other unit which has been used in all required tests. Water circulation has been used for cooling of the PV module to and very fine soil used to estimate the effect of each of hot weather and dust deposition on the performance of PV respectively. The results show that the fill factor (FF) and PV efficiency affected inversely with increasing in temperature, on the other hand cooling process contributed to increase the voltage generation across PV panel by $11.8 \%$, while the reduction in voltage generation by unclean panel due to natural pollution deposition on the front of the panel for a period of three months was about 3.8\% compared with clean panel and $13.8 \%$ if it has been compared with voltage production by panel when it has been cooled by water.
\end{abstract}

Keywords: Photovoltaic, Performance of PV, Efficiency of PV

\section{Introduction}

Renewable energy is generated from natural resources such as the sun, wind, and water, using technology which ensures that the energy stores are naturally replenished, and they are becoming more and more attractive especially after deterioration of the environment pollution and the constant fluctuation in oil price. Solar energy has been encouraged to substitute conventional energy. It has good potential and the direct conversion technology based on solar photovoltaic has several positive attributes especially in remote area $[1,2]$. The physical process in which a photovoltaic (PV) cell converting sunlight directly into electricity through semiconductor diode tight into direct current (DC). One single PV cell produces up to 2 watts of power at approximately $0.5 \mathrm{~V} \mathrm{DC}$, many $\mathrm{PV}$ cells are connected together to form modules (panels) to increase power output which are further assembled into large units called arrays [3]. The inherent material property of these semi-conductor limits of PV system efficiency of the photovoltaic system within $15-20 \%$ [4]. The performance of PV systems is affected by several parameters including environment conditions. There are several studies in the field of environmental conditions such as (temperature, dirt accumulation and wind speed). Herein we review some of them: Kaldellis and Kokala [5] investigated an experimental analysis was conducted in the laboratory soft energy application and environmental protection (SELAB) to determine the effect of pollution on the energy performance of PV-panels quantitatively. Majid et al. [6] showed that the efficiency of PV cell decrease $0.485 \%$ per $1^{\circ} \mathrm{C}$, after the surface temperature increase than $25^{\circ} \mathrm{C}$. Elhab B. R. et al. [7] presented a mathematical approach to determine optimum tilt angles for solar collector. Kaldellis et al. [8] introduced an experimental study to determine the reduction in efficiency of photovoltaic due to deposition of natural air pollution on the PV panels, where they concluded that the efficiency has been decreased by $0.4 \%$ per month, when it is exposure to outdoor without cleaning. Dincer F. and Meral M. E. [9] studied several factors effect on solar cell efficiency such as changing of cell temperature, using maximum power point tracking (MPPT) with solar cell and energy conservation efficiency for solar cell. Bhattacharya et al. [10] presented a statistical analysis method to determine 
the effect of ambient temperature and wind speed on the performance of the photovoltaic model. Tianze et al. [11] presented a new technologies to improve the conversion efficiency of PV model and to reduce the cost of it. Hamrouni et al. [12] and Hosseini et al. [13] improved the operation PV systems by spraying water over front of the photovoltaic cells. Rajput D. S. and sudhakar [14] studied the effect of environment dust on power production by PV experimentally, and they obtain that the power production reduced by $92.11 \%$. Sulaiman et al. [15] provided an experimental study by using different obstruction materials conducted under controlled conditions using spotlight substitute for sunlight. The result which was obtained from external resistance could reduce the efficiency by $85 \%$.

The goal of this study is to determine the effect of environmental conditions on the electrical power production of PV cells experimentally in Kirkuk city, Iraq. The study was accomplished by using two identical PV modules, one then used as a reference panel and its performance has been compared with the second module, when water circulation used for cooling the PV cell and very fine soil used as natural dust pollution deposition on the frontal surface for the PV module.

\section{Experimental Methodologies}

This study is conducted by using two Photovoltaic cells of $75 \mathrm{~W}$ and they were mounted on the angular movable stand and control board as shown in Fig. (1). These two PV modules has been connected to battery source by control board which contains to solar charge controller (CMTP02), 4 channel signal recorder (velleman) was used for instantaneous recording of DC voltage generation from PV cells, electric DC lamp 50W used as electrical load and current flow in electrical circuit measuring by Professional digital multimeter (ST-9915) as shown in Fig. (2). Weather station type (Wireless weather station HP2000) as shown in Fig. (3), has been used to record the required data about testing place (Al-Wasity, Kirkuk / Iraq) weather condition during all experiment and the latitude and longitude of the location are $35.24 \mathrm{~N}$ and $44.21 \mathrm{E}$ respectively. Three sets of experiments to show the effects of environmental conditions on the performance of PV cells, as follows:-

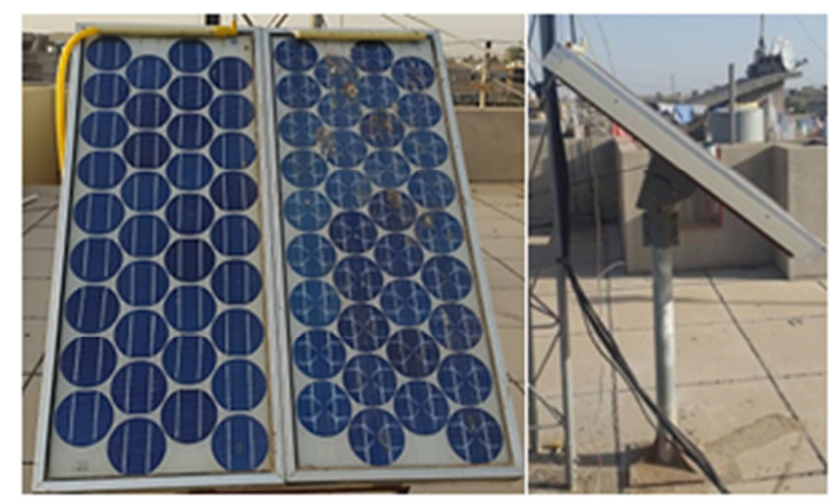

Fig. 1. Installation of PV test modules on the base.

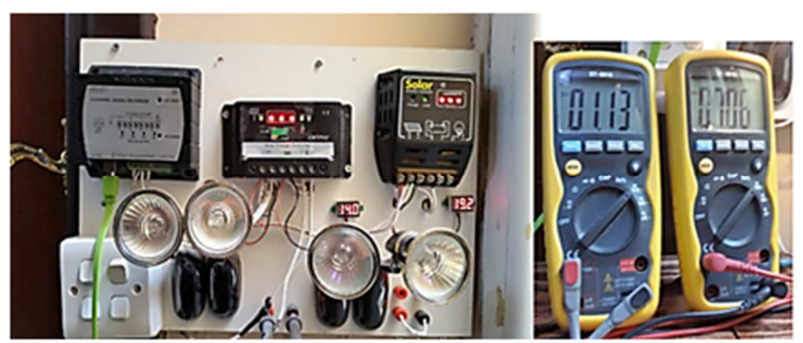

Fig. 2. Components of control board.

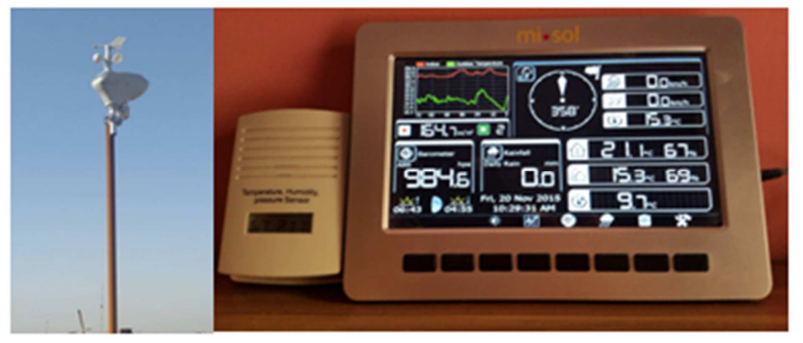

Fig. 3. Photographic of professional wireless weather station.

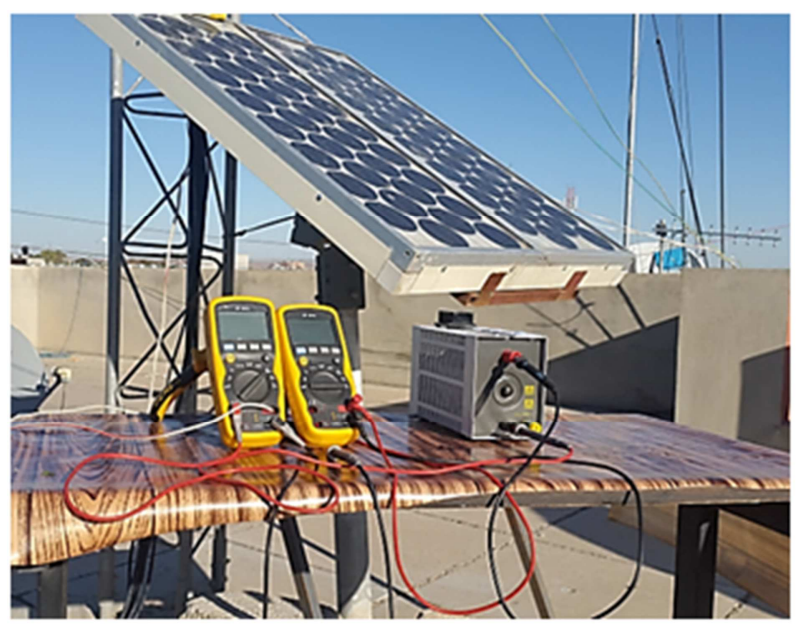

Fig. 4. Instruments used in test of PV characteristics.

\subsection{The Influence of Temperature on the PV Characteristics}

The effect of temperature was investigated by using two commercially PV cells of $75 \mathrm{~W}$. One of them is used as conventional reference panel and the other module has been used for executing experiments by adding a water circulation to it, as shown in Fig. (3), their purpose is to control surface temperature of PV cell through water flow on the upper layer of PV cell at constant temperature, to insure that the surface temperature has reached to steady state. The range of water temperatures were used at $(5,10,20,40,50,60,70)^{\circ} \mathrm{C}$. PV characteristic experiments in different surface temperatures have been conducted by connecting precision variable resistor, ammeter and voltmeter to the PV cell as shown in Fig. (4). The principle of the PV characteristic in each experiment is measuring each of voltage potential across variable resistance and current flow for each resistance value, where that the procedures of the test begins by changing the resistance from zero ohm (open circuit) up to maximum 
resistance value (closed circuit) gradually by variable resistor device. Will the obtained data has been used to sketch a relation between each of voltage vs electric current and voltage vs power production as shown in Fig. (5).

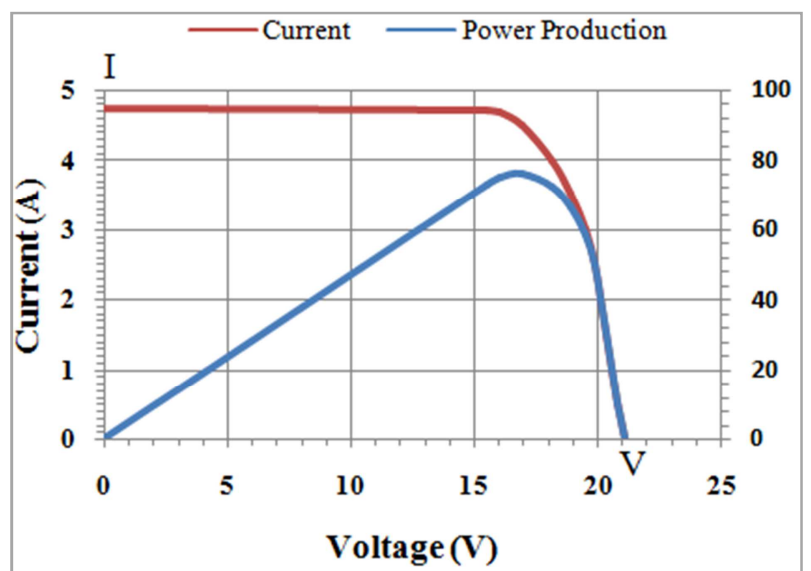

Fig. 5. Typical $I-V$ and $P-V$ characteristics of solar cell at standard condition test.

The maximum power $\left(P_{\max }\right)$ was calculated using measured maximum current $I_{m p}$ and maximum voltage $I_{m p}$ $[16,17]$.

$$
P_{\text {max }}=I_{m p} \times I_{m p}
$$

and maximum power can be calculated according to the short circuit current $I_{S c}$ and open circuit voltage $[9,18,19]$.

$$
P_{\text {max }}=F F\left(I_{s c} \times V_{o c}\right)
$$

where $F F$ Fill factor of solar cell. It is essentially measure of quality of the solar cell, can be interpreted graphically as the ratio of the rectangular areas depicted in Fig. (6).

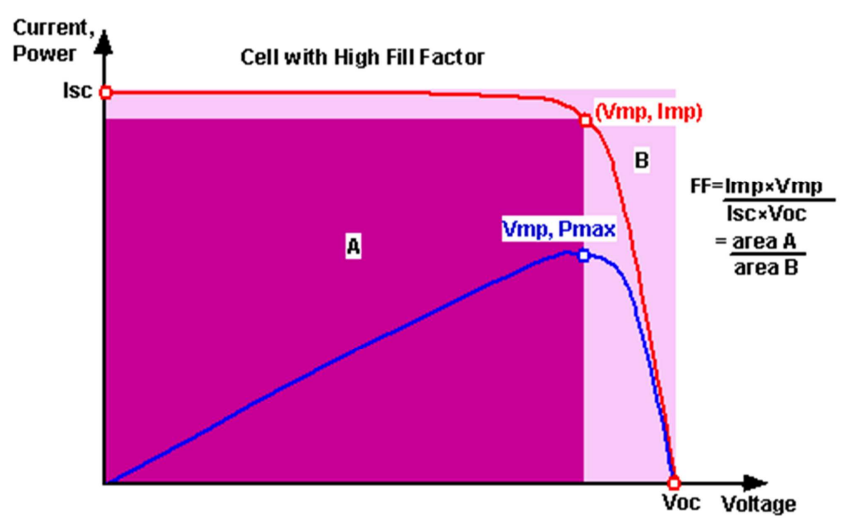

Fig. 6. A typical current-voltage and maximum power curve [18].

According to the above definition and Fig (6), the FF can be expressed as

$$
F F=\frac{\operatorname{area} A}{\operatorname{area~} B}=\frac{I_{m p} \times V_{m p}}{I_{S c} \times V_{o c}}
$$

The solar cell efficiency $\eta$ is calculated using the ratio of the maximum power produced divided by the input light irradiance $\left(G, \mathrm{~W} / \mathrm{m}^{2}\right)$ and solar cell area $\left(A_{c}, \mathrm{~m}^{2}\right)$. Following relation was used for the calculation of model efficiency.

$$
\eta=\frac{P_{\max }}{G \times A_{c}}
$$

Substituting Eq. (3) into Eq. (4)

$$
\eta=\frac{F F \times V_{o c} \times I_{S c}}{G \times A_{c}}
$$

It turns out that both the open circuit voltage and the fill factor decrease substantially with temperature, while short circuit current increase slightly. Thus the net effect leads to a linear relation in the form $[20,21]$.

$$
\eta=\eta_{\text {Tref }}\left[1-\beta_{\text {ref }}\left(T_{c}-T_{\text {ref }}\right)+\gamma \log _{10} G\right]
$$

where $\eta_{\text {Tref }}$ is the module's electrical efficiency of $15.6 \%$ at a reference temperature $T_{\text {ref }}$ of $25^{\circ} \mathrm{C}$ and solar radiation flux of $1000 \mathrm{~W} / \mathrm{m}^{2}, \beta_{\text {ref }}$ is the temperature coefficient, with respect to temperature $0.0045 \mathrm{~K}^{-1}$ and $\gamma$ is mainly material properties and equal to 0.12 for crystal silicon modules. Thus, the latter term from Eq. (6) is usually taken as zero [22]. Then Eq. (6) reduces to

$$
\eta=\eta_{\text {Tref }}\left[1-\beta_{\text {ref }}\left(T_{c}-T_{\text {ref }}\right)\right]
$$

where the quantities of $\eta_{\text {Tref }}$ and $\beta_{\text {ref }}$ are given by PV manufactures. The actual value of the temperature coefficient, in particular, depends not only on the PV material but on $T_{r e f}$, as well. It is given by the ratio

$$
\beta_{\text {ref }}=\frac{1}{T_{0}-T_{\text {ref }}}
$$

$T_{c}$ is the module operating temperature varies according to global solar irradiance, $G$ and mean monthly ambient temperature, $T_{a}$ are related as in Eq.(9), [23, 24]:

$$
T_{c}-T_{a}=\left(219+823 K_{t}\right) \frac{N O C T-20}{800}
$$

there is another method used to calculate cell temperature based on monthly mean of solar irradiance, $G_{b}$ and ambient temperature, and NOCT is normal operating cell temperature [25].

$$
T_{c}=T_{a}+\left(\frac{N O C T-20}{800}\right) G_{b}
$$

In which $T_{0}$ is the temperature at which the PV module's electrical efficiency drops to zero, for crystalline silicon cells this temperature is $\left(270^{\circ} \mathrm{C}\right)$.

Also there is a new approach for estimating the operating temperature of photovoltaic model using statistical formula with an error of less than $3 \%$, based on the steady state approach prediction as [26]:

$$
T_{c}=0.943 \times T_{a}+0.195 \times G-1.528 \times U+0.3529(11)
$$

\subsection{Effect of Temperature on the Power Production of the PV Module}

To investigate the performance of PV module in environment that is hotter than standard condition is done 
by using electric load which provided the power by power supply system which contains a battery (12V 36AH), PV module and solar charge controller (CMP02). For this purpose two tests on the PV module were done by starting the load of $(100 \mathrm{~W})$ for period of $450 \mathrm{sec}$. and then shut down the power source, while the charging process to the battery was continuous until the battery becomes fully charge. To achieve this goal we used voltage data logger (Velleman PCLAB 2000SE) to obtain high accuracy data. The first test was done by using the PV module in normal condition and the other test was done by using the cooling process to the PV module. The performance of the module was estimated by reduction in charging time of the battery, and calculated as:

$\%$ Reduction in time of battery charging $=\frac{\Delta t_{1}-\Delta t_{2}}{\Delta t_{1}} \times 100$

where $\Delta t_{1}$ and $\Delta t_{2}$ are time of battery charging for first and second cases respectively.

\subsection{Estimation of Dust Impact on the Performance of the PV Module}

The effect of dust deposition on the front surface of the PV was investigated by using two identical cells used in previous tests and it was estimated by comparing between performance of clean and dirty cells. The experiments were done based on the density of the dust on the front of the PV by using five different dust pollution mass depositions were selected as $(0.05,0.10 .5,1.0$ and 2.0$) \mathrm{g} / \mathrm{m}^{2}$ with average diameter of $(0.005 \mathrm{~mm})$. The dust deposition density $(\Delta \mathrm{M}$, $\left.\mathrm{g} / \mathrm{m}^{2}\right)$ is expressed as [5]:

$$
\Delta M=\frac{\Delta m}{A_{c}}
$$

where $\Delta m$ is the total mass of dust layer on the surface of the polluted PV cells in $(g)$ and $A_{c}$ is the cell area in $\left(\mathrm{m}^{2}\right)$. The output parameters of PV cells are recorded in each values of dust deposition density under four different environment conditions by expose PV cells directly to the atmospheric and when the temperature of the frontal surface of the PV cells range from 40 to $60^{\circ} \mathrm{C}$. Start from $8 \mathrm{am}$, and ends at $1 \mathrm{pm}$ for ten days in second-third of July, 2015. The average of the results of these experiments is used to estimate the influence of dust pollution on the PV performance. The reduction in performance of PV calculated by using following relations $[14,16]$ :

$$
\% \text { Reduction in power production }=\frac{P_{\text {clean }}-P_{\text {dirty }}}{P_{\text {dirty }}} \times 100
$$

and

$\%$ Reduction in PV Cell efficiency $=\frac{\eta_{\text {clean }}-\eta_{\text {dirty }}}{\eta_{\text {dirty }}} \times 100$

\section{Results and Discussion}

A professional wireless weather station was used to record the input data of the environmental conditions during test times; also the DC data logger was used to record output parameters from the PV cells with minimum error. From results which were obtained through three sets of experiments on the two identical PV cells to study environment effect from the following aspects:

\subsection{The First Aspect: Study of the PV cell characteristics in Different Surface Temperature}

Figs. (7 and 8) shows the I-V characteristics of PV cell tests at different temperature conditions, as we noted that the temperature greatly was effected by the power production from solar module, so any increases in ambient temperature than standard condition $25^{\circ} \mathrm{C}$, it will have negative effect on the PV performance, and vice versa, also we noted that the $\mathrm{PV}$ cell gives the maximum power at $5^{\circ} \mathrm{C}$, while the minimum power gives at $60^{\circ} \mathrm{C}$, as shown in fig. (9), as shown in fig. (9), and from there, we find a mathematical expression for each of fill factor and actual efficiency of module $\left(\mathrm{FF}=-6 \mathrm{E}-06 \mathrm{~T}^{2}-0.0007 \mathrm{~T}+0.7899\right)$ and $(\eta=-3 \mathrm{E}-$ $\left.06 \mathrm{~T}^{2}-0.001 \mathrm{~T}+0.2345\right)$ respectively.

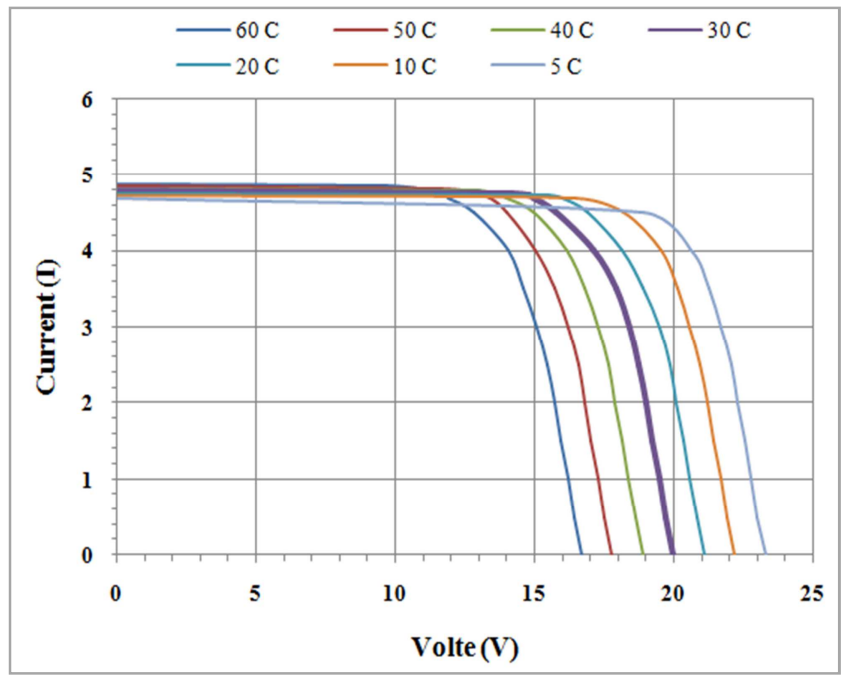

Fig. 7. I-V characteristic of different surface temperature.

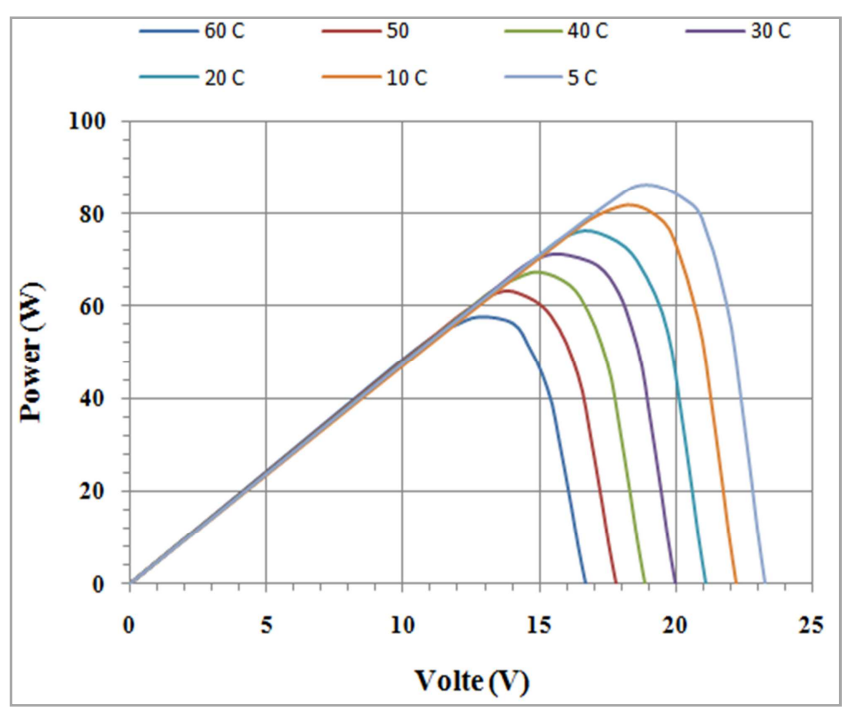

Fig. 8. P-V characteristic of different surface temperature. 


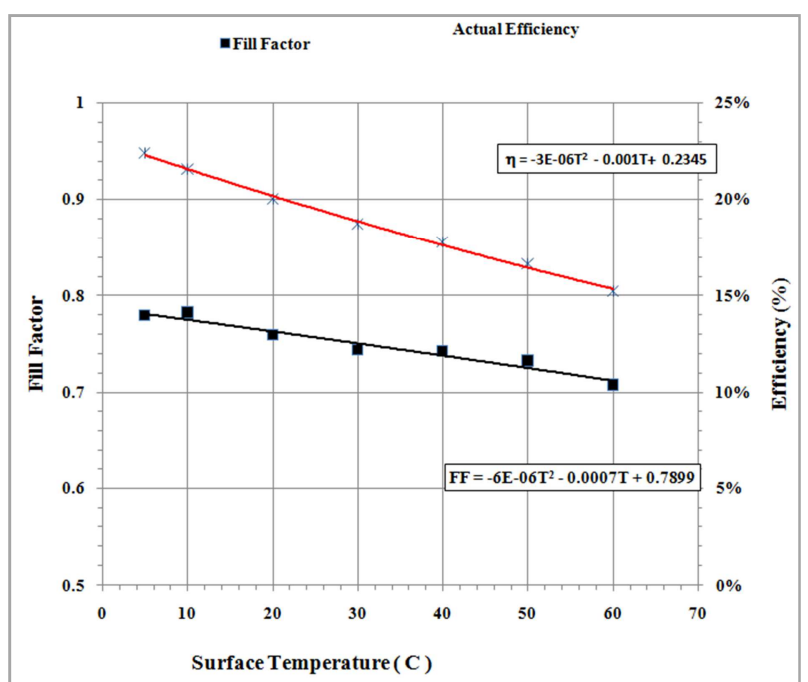

Fig. 9. Relation between fill factor and efficiency with surface temperature PV cell.

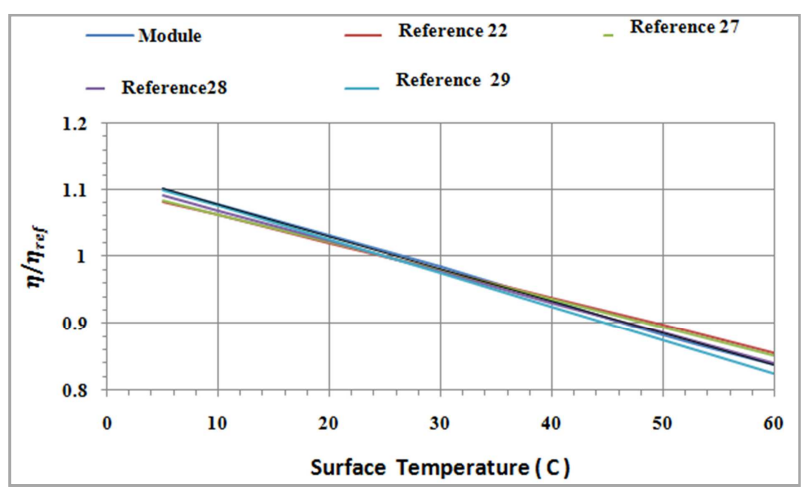

Fig. 10. The ratio $\left(\eta / \eta_{\text {ref }}\right)$ for $P V$ module compared with correlations predicted by previous References.

The actual efficiency of the present PV module has been compared with the empirical relations in Table (1) that put to connect the ratio of actual efficiency to the standard condition efficiency with surface temperature of the module. The comparison result appears they approximately conforming to the results of these correlations and with accuracy about $\pm 2 \%$ as shown in Fig. (10).

Table 1. Empirical Relations.

\begin{tabular}{ll}
\hline Correlation & Ref. \\
\hline$\eta=\eta_{\text {Tref }}\left[1-\beta_{\text {ref }}\left(T_{c}-T_{\text {ref }}\right)\right]$ & 22 \\
$\eta=\eta_{\text {ref }}-\mu\left(T_{c}-T_{\text {ref }}\right)$ & 27 \\
$\eta=\eta_{25}-b\left(T_{c}-25\right)$ & 28 \\
$\eta_{\left(G T, T_{C}\right)}=\eta_{(G T, 25)}\left[1+c_{3}\left(T_{c}-25\right)\right.$ & 29 \\
\hline
\end{tabular}

where $\mu$ is overall cell temperature coefficient, $b=b\left(G_{T}\right)$ and $c_{3}=-0.5 \%$ loss per ${ }^{\circ} \mathrm{C}$

\subsection{The Second Aspect: Study of Electrical Power Production at Different Surface Temperature}

The PV unit has been operated in two cases in July 24, 2015. The first case at 9 am, PV module operated in conventional case when surrounding temperature was $48^{\circ} \mathrm{C}$ and solar radiation $\left(746 \mathrm{~W} / \mathrm{m}^{2}\right)$ and battery charging watching by 4 channel signal recorder as shown in Fig. (11). At the beginning of the test, the battery was fully charged, and PV cell works as in open circuit and it generated a voltage of $18.36 \mathrm{~V}$, when the power start-On to two lamps during $431 \mathrm{sec}$ with voltage supply of $12.07 \mathrm{~V}$ and then power source cut off from lamps and then we will wait until the battery charging reaches to initial level, and this needs to $1362 \mathrm{sec}$ in this case, and these about 8.4 times of working time for lamps. In second case, time of experiment at $2 \mathrm{pm}$, when ambient temperature is $51^{\circ} \mathrm{C}$ and solar radiation 930 $\mathrm{W} / \mathrm{m}^{2}$, where we used water circulating with controlled temperature of $25^{\circ} \mathrm{C}$. This process contributed to increase the level of voltage generation from 17.8 to $19.9 \mathrm{~V}$, as shown in Fig. (12), and the ratio of improvement in voltage generation was about $11.8 \%$. When power was supplied to the lamps for the same period in the first case, in this case, battery was fully charging faster than first case by $50 \%$.

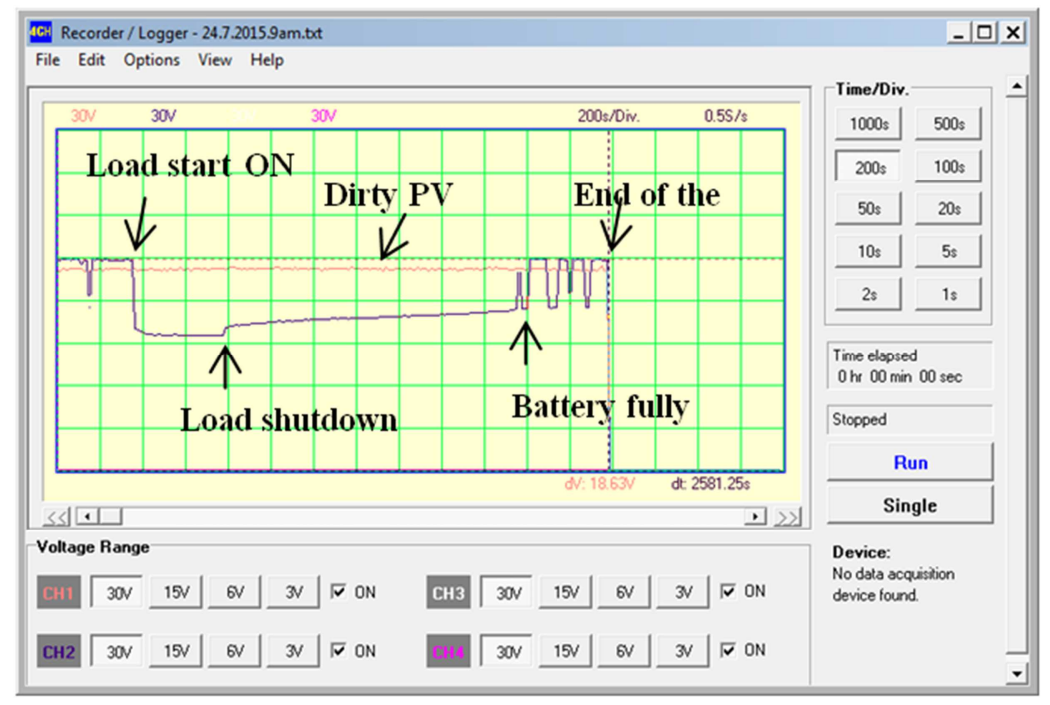

Fig. 11. System operation performance for normal use. 


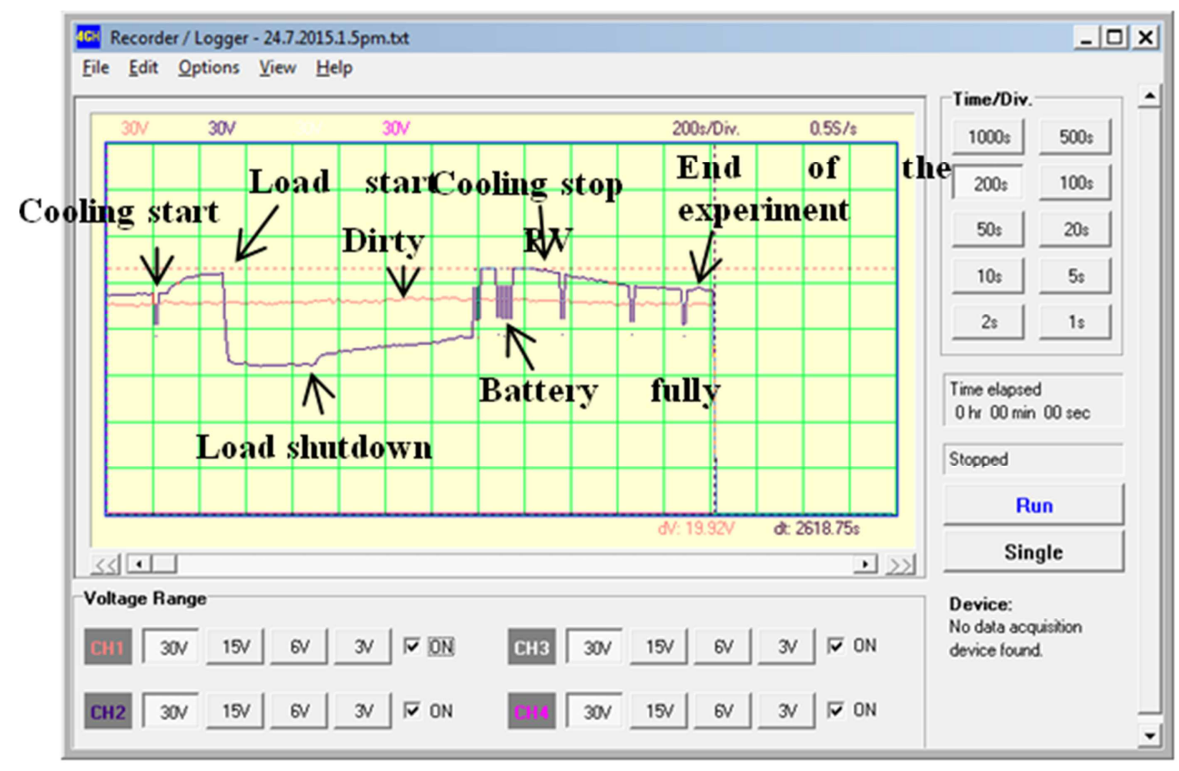

Fig. 12. System operation performance with cooling process.

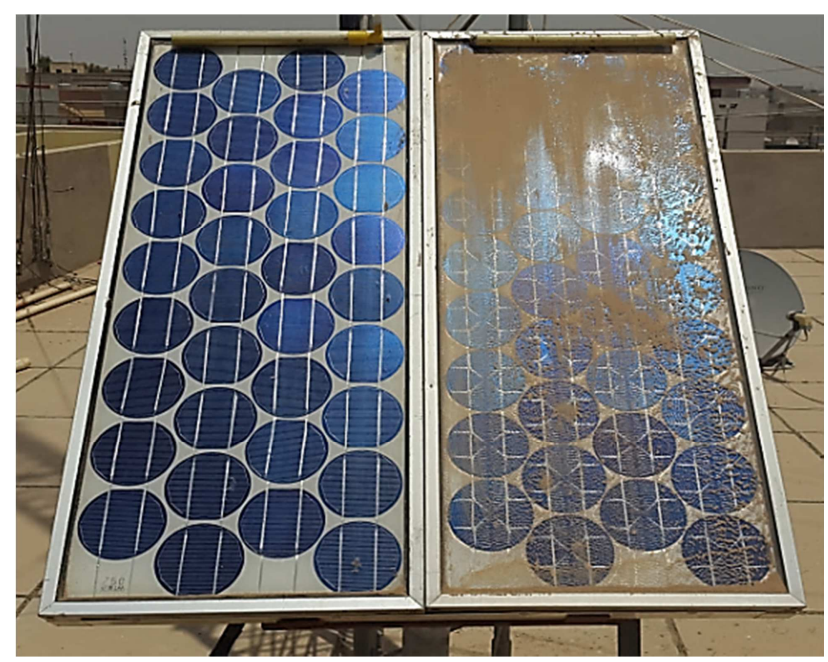

Fig. 13. Dust pollution disposition on the PV test module.

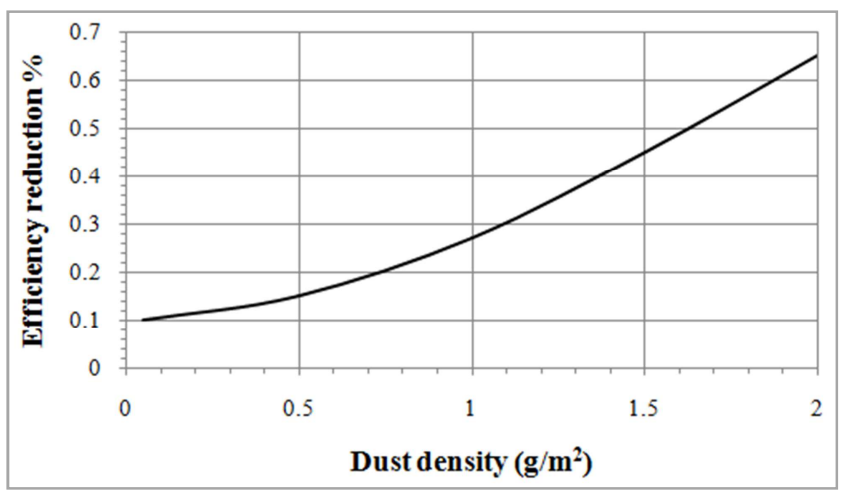

Fig. 14. Efficiency differences between the clean and polluted PV module at different of dust density on the frontal surface.

\section{Conclusions}

Experiments results refer to that the environmental conditions has great effect on the PV module performance, to improve its performance and should be done by periodic maintenance process on the PV module from dust deposition and add suitable size of PV panels to compensate for the shortfall, which occurs in power production of the PV unit due to hot weather and that cannot be controlled.

\section{References}

[1] Bataineh K. and Dalalah D., Optimal configuration for design of stand-alone PV system, Smart Grid and Renewable Energy, V. 3, pp. 139-147 (2012).

[2] Ma J., Man K. L., Ting T. O., Zhang E. G., Guan S., Wong P. W., Krilavicius T., Sauleviius D., and Lei C. U., Simple Computational method of predicting electrical characteristics in solar cell, Elektronika IR Elektrotechnka, V. 20, No. 1, pp.41-44, (2014).

[3] Muzathik A. M., Photovoltaic modules operating temperature estimations using a simple correlation, International Journal of Energy Engineering, V. 4, Iss. 4, pp. 151-158, (2014).

[4] Mani M. and Pillai R., Impact of dust on solar photovoltaic performance: Research status, challenges and recommendations, Renewable and Sustainable Energy Reviews, V. 14, pp. 3124-3131, (2010).

[5] Kaldellis J. K. and Kokala A., Simulating the dust effect on the energy performance of photovoltaic generates based on experimental measurements, Energy, V. 36, pp.5154-5161, (2011).

[6] Majid Z. A. A., Ruslan M. H., Sopian K., Othman M. Y. and Azmi M. S. M., Study on performance of 80 Watt floating photovoltaic panel, Journal of Mechanical Engineering and Sciences, V. 7, pp. 1150-1156, (2014).

[7] Elhab B. R., Sopian K., Mat S., Lim C., Sulaiman M. Y., Ruslan M. H. and Saadation O., Optimizing tilt angles and orientation of solar panels for Kuala Lumpur Malaysia, Scientific Research and Essays, v. 7, No. 42, pp. 3758-3765, (2012). 
[8] Kaldellis J. K. and Kokala A., Quantifying the decease of the photovoltaic panels energy yield due to phenomena of natural air pollution disposal, Energy V. 35, pp. 4862-4869, (2010).

[9] Dincer F. and Maral M. E., Critical factors that affecting efficiency of solar cells, Smart Grid and Renewable Energy, V.1, pp. 47-50, (2010).

[10] Bhattacharya T., Chakraborty A. and Pal K., Effects of ambient temperature and wind speed on performance of Monocrystalline solar photovoltaic module in Tripura, India, Journal of Solar Energy, Article ID 817078, (2014).

[11] Tianze L., Xia Z., Chuan J. and Luan H. Methods and analysis of factors impact on the efficiency of the photovoltaic generation, Journal of Physics, Conference Series 276, (2011).

[12] Hamroni N., Jradi M. and Cherif A., Solar radiation and ambient temperature effects on the performances of a PV pumping system, Revue des Energies Renouvelables, V. 11, No.1, pp. 95-16, (2008).

[13] Hosseini R., Hosseini N. and Khorasanizadeh H., An experimental study of combining system with a heating system, Word Renewable Energy Congress 2011-Swiden, pp. 2993-3000, (2011).

[14] Rajput D. S. and Sudhakar K., Effect of dust on the performance of solar panel, International Journal of Chem Tech Research, V. 5, No. 2, pp. 1083-1086,(2013).

[15] Sulaiman S. A., Singh A. K., Mokhtar M. M. and Bou-Rabee M. A., Influence of dirt accumulation on performance of PV panels, Energy Procedia V.50, pp. 50-56, (2014).

[16] Ali H. M., Zafar M. A., Bashir M. A., Nasir M. A., Ali M. and Siddiqui A. M., Effect of dust deposition on the performance of photovoltaic modules in Taxila, Pakistan, Thermal Science, Online, First Issus (00), pp-46-46, (2015).

[17] Mohamed A. O. and Hasan A., Effect of dust accumulation on performance of photovoltaic solar modules in Sahara environment, Journal of Basic and Applied Science Research, V. 2, No. 11, pp. 11030-11036, (2012).

[18] Raina G., Mandal S., Shinda S., Patil M. and Hedau R., A novel technique for $\mathrm{PV}$ panel performance prediction, International Journal of Computer Application, International Conference and Workshop on Emerging Trends in Technology 2013, pp. 19-24, (2013).

[19] Pandey A. K., Pant P. C., Sastry O. S., Kumar A. and Tyagi S.
K., Energy and exrgy performance evaluation of typical solar photovoltaic module, Journal of Thermal Science, Online First Issus (00), pp. 147-147, (2013).

[20] Skoplaki E. and Palyvos J. A., On the temperature dependence of photovoltaic module electrical performance: A review of efficiency/ power correlations", Solar Energy, V. 83, pp. 614624, (2009).

[21] Dubey S., Sarvaiya J. N. and Seshadri B., Temperature dependent photovoltaic efficiency and its effect on PV production in the World- A review, Energy Procedia, V. 33, pp. 311-321, (2013).

[22] Evans D., Simplified method for predicting photovoltaic array output, Solar Energy, V. 27, pp. 555-560, (1981).

[23] Mehmood A., Waqas A. and Mahmood H. T., Stand-alone system assessment for major cities of Pakistan based on simulated results; A comparative Study, Nust Journal Engineering Sciences, V.1, No.1, pp. 33-37, (2013).

[24] Rahman H. A., Nor K. M. and Hassan M. Y., The impact of meteorological factors on energy yields for the building integrated photovoltaic system in Malaysia, Solar09, the $47^{\text {th }}$ ANZSES Annual Conference 2009 Townsville, Queensland, Australia, (2009).

[25] Benatiallah A., Mostefaoui R., Boubekri M. and Boubekri N., A simulation model for sizing PV installations, Desalination, V.209, pp.97-101, (2007).

[26] Muzathik A. M., Photovoltaic modules operating temperature estimation using a simple correlation, International Journal of Energy Engineering, V. 4, Iss.4, pp. 151-158,(2014).

[27] Bazilian M., Prasad D. Modeling of a photovoltaic heat recovery system and its role in a design decision support tool for building professionals, Renewable Energy 27, pp. 57-68, (2002).

[28] Durisch W., Urbon J., Smestad G. Characterization of solar of solar cells and modules under actual operations, Renewable Energy 8, pp. 359-366, (1996).

[29] Mohring H. D., Stellbogen D., Schaffler R., Oelting S., Gegenwart R., Konttinen P., Carlsson T., Cendagorta M., Hermann W., Outdoor performance of polycrystalline thin fin film PV modules in different European climates, Proceeding of $19^{\text {th }}$ EC Photovoltaic Solar Energy Conference, June 711,2004, Paris, France. 